\title{
ENDOTHELIN-3 LIKE IMMUNOREACTIVITY IN PLASMA OF PATIENTS WITH CIRRHOSIS OF THE LIVER
}

\author{
Veit Gülberg, Alexander L. Gerbes, Angelika M. Vollmar ${ }^{1}$ \\ and Gustav Paumgartner \\ Department of Medicine II, Klinikum Grosshadern and \\ ${ }^{1}$ Institute of Pharmacology, Toxicology and Pharmacy, University of Munich, \\ W-8000 Munich, Federal Republic of Germany \\ (Received in final form July 27, 1992)
}

\begin{abstract}
Summary
A highly specific and sensitive radioimmunoassay (RIA) has been established for determination of endothelin-3 like immunoreactivity in human plasma to investigate its possible role in hemodynamic alterations due to liver disease. Crossreactivity with other endothelin isoforms was always below $4 \%$, the lower detection limit following extraction on Sep-Pak C18 cartridges was $0.5 \mathrm{pg} / \mathrm{ml}$. The concentration of endothelin-3 (mean \pm SEM) was $4.16 \pm 0.56 \mathrm{pg} / \mathrm{ml}(\mathrm{n}=13)$ in plasma of patients with cirrhosis of the liver, three fold higher than in age matched controls $(1.35 \pm 0.27 \mathrm{pg} / \mathrm{ml}, \mathrm{n}=12, \mathrm{p}<0.01)$. Plasma immunoreactivity was confirmed to be endothelin-3 related by reverse-phase HPLC. These data could suggest a role of plasma endothelin- 3 in circulatory changes, as they occur in cirrhosis of the liver.
\end{abstract}

Endothelin-1 (ET-1), a 21 amino acid peptide with potent vasoconstrictor activity (1) has been investigated in a variety of cardiovascular and endocrine diseases to establish its possible role in the pathophysiology of these disorders (for review see 2,3). As yet there is only scarce information about endothelin-3 (ET-3) which differs from ET-1 by six amino acids (4). However, determination of circulating ET-3 is of considerable interest regarding the different pharmacological properties of ET-3 and ET-1 (4-6). ET-3 has been shown to act as a vasodilator $(7,8)$ and therefore may play a role different from ET-1 in various pathophysiological conditions.

Hemodynamic changes in cirrhosis of the liver are characterized by peripheral vasodilation (9), however the responsible agent has not been identified so far. Vasodilating substances which are released into the intestinal circulation and cleared to a lesser extent by the cirrhotic liver are candidates in this respect. Since the intestine has been shown to be a major site of ET-3 synthesis (10) one might speculate, that ET-3 plasma levels could be increased in chronic liver disease, thus contributing to the aforementioned hemodynamic alterations. Therefore we established a RIA to investigate circulating ET-3 in patients with cirrhosis of the liver.

Corresponding author: Alexander L. Gerbes, Dept. of Medicine II, Klinikum Grosshadern, University of Munich, Marchioninistr. 15, W-8000 Munich 70, FRG.

The presented data are part of a doctoral thesis of V. Gülberg at the Faculty of Medicine, LudwigMaximilians Universität, Munich. 


\section{Materials and Methods}

Blood samples: Venous blood samples were obtained from 12 healthy volunteers (age $52 \pm 4$ years) and 13 patients with cirrhosis of the liver ( $54 \pm 3$ years old). Blood was transferred into precooled tubes containing EDTA $(1 \mathrm{mg} / \mathrm{ml})$ and then centrifuged at $1500 \times \mathrm{g}$ for $10 \mathrm{~min}$. at $4^{\circ} \mathrm{C}$. Samples were stored at $-70^{\circ} \mathrm{C}$.

Plasma extraction: Plasma samples $(1 \mathrm{ml})$ were acidified with $2 \mathrm{ml}$ acetic acid $(4 \%)$ or $1 \mathrm{ml}$ of trifluoroacetic acid (TFA) $(0.1 \%)$ and centrifuged at $2500 \mathrm{x} \mathrm{g}$ for $10 \mathrm{~min}$. The supernatant was applied to Sep-Pak C18 cartridges (Waters, Milford, MA), which had been activated with $10 \mathrm{ml}$ of acetone, water, methanol and acetic acid (4\%) consecutively. Cartridges were then washed with $10 \mathrm{ml}$ of $50 \mathrm{mM}$ TrisHCl buffer $(\mathrm{pH} \mathrm{7.4)}$ and eluted with $3 \mathrm{ml}$ of acetonitrile / $0.026 \mathrm{M}$ ammonium acetate $(60 \% / 40 \%)$. Eluates were dried down in a speed-vac concentrator. Extraction recovery was evaluated by adding increasing concentrations of synthetic ET-3 (Nova Biochem, Läufelfingen, Switzerland) to plasma samples prior to extraction.

Radioimmunoassay: RIA for ET-3 was carried out in $0.02 \mathrm{M}$ phosphate buffer (pH 7.4), containing $0.15 \mathrm{M} \mathrm{NaCl}, 0.01 \%$ bovine serum albumin, $0.1 \%$ gelatine, $0.01 \%$ thimerosal and $0.1 \%$ Triton X100. Samples or diluted standard of ET-3 were reconstituted to $350 \mu \mathrm{l}$ and $100 \mu \mathrm{l}$ of antibody RAS 6911N (Peninsula, London, UK, final dilution 1: 100000) was added. After a $24 \mathrm{~h}$ incubation period $10000 \mathrm{cpm}$ of [125] ET-3 (Amersham, Braunschweig, FRG, specific activity $2000 \mathrm{Ci} / \mathrm{mmol}$ ), diluted in $50 \mu \mathrm{l}$ of assay buffer were added, followed by another $24 \mathrm{~h}$ incubation. Separation of the bound ligand was then performed by adsorption of the free ligand to albumin coated charcoal, followed by centrifugation. The supernatant was counted in a LKB gamma counter (Turku, Finland).

Reverse-phase HPLC: Pooled plasma was extracted as described above. The dried residue was reconstituted in $100 \mu 10.1 \%$ TFA, loaded on a C18 reverse phase HPLC column $(0.39 \times 30 \mathrm{~cm}$, $\mu$ Bondapak, Waters, Milford, MA) and eluted with a linear gradient of acetonitrile from 20 to 50 $\%$ during $60 \mathrm{~min}$. in $0.1 \%$ TFA (flow rate $1 \mathrm{ml} / \mathrm{min}$., fraction size $1 \mathrm{ml}$ ). Collected fractions were lyophilized and subjected to RIA.

Statistical analysis: Data are given as mean and standard error. Plasma levels were not corrected for recovery. Mean values were compared by the student's t-test. A p-value of less than 0.05 was considered as statistically significant.

\section{$\underline{\text { Results }}$}

The lower detection limit of the established RIA was $0.5 \mathrm{pg} / \mathrm{ml}$ plasma. Serial dilutions of extracted plasma from healthy volunteers and cirrhotic patients paralleled the standard curve (fig. 1). Intra- and interassay variations, employing eight samples, were $10.7 \pm 1.9 \%(\mathrm{n}=5)$ and 16.5 $\pm 2.3 \%(n=4)$, respectively. Crossreactivity of antibody RAS $6911 \mathrm{~N}$ was $2.6 \%$ for ET-1, $2.7 \%$ for ET-2, $3.7 \%$ for big ET- 1 and $100 \%$ for the precursor big ET-3; the specificity of the antiserum was furthermore proven by reverse-phase HPLC of ET-3 like immunoreactivity.

Common extraction procedures for ET-1, using $4 \%$ acetic acid for dilution of plasma samples, yielded poor recovery rates: $37.9 \%, 21.5 \%$ and $7.7 \%$ for $3.9,7.8$ and 31.3 pg ET-3, respectively. Therefore we diluted plasma with $0.1 \%$ TFA followed by centrifugation prior to application onto extraction cartridges. Thereby, extraction recoveries of $3.9,7.8$ and $31.3 \mathrm{pg}$ synthetic ET-3 were raised to $89.3 \pm 1.2 \%, 75.1 \pm 8.9 \%$ and $58.3 \pm 10.6 \%$ in controls $(\mathrm{n}=5)$ and $93.1 \pm 6.8 \%, 92.7$ $\pm 7.8 \%$ and $72.2 \pm 8.1 \%$ in cirrhotic patients $(\mathrm{n}=5)$.

Circulating ET-3 was significantly higher $(\mathrm{p}<0.01)$ in patients with cirrhosis $(4.16 \pm 0.56 \mathrm{pg} / \mathrm{ml})$ as compared to age matched healthy controls $(1.35 \pm 0.27 \mathrm{pg} / \mathrm{ml}$, fig. 2$)$. Immunoreactivity was shown to be ET-3 related by reverse-phase HPLC (fig. 3 ). 


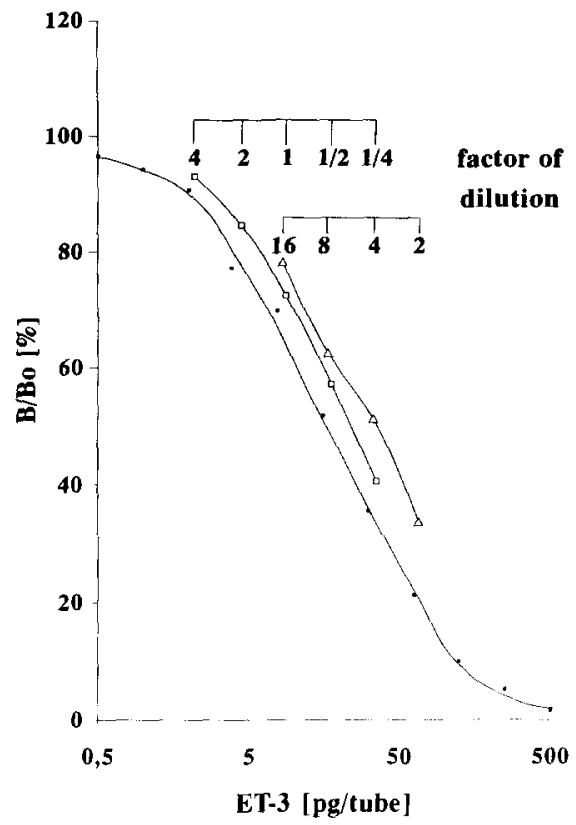

FIG. 1

A typical standard curve for the radioimmunoassay of ET-3. Serial dilutions of plasma from healthy controls (squares) and cirrhotic patients (triangles) parallel the standard curve.

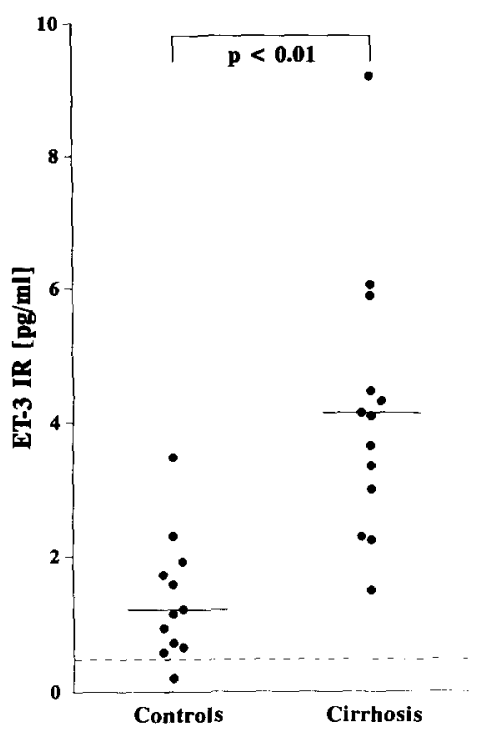

FIG. 2

Plasma ET-3 concentrations in healthy subjects $(\mathrm{n}=12)$ and in patients with cirrhosis of the liver $(n=13)$. The scattered line indicates the lower detection limit of the radioimmunoassay. Plasma concentrations in patients $(4.16 \pm 0.56 \mathrm{pg} / \mathrm{ml})$ were significantly $(\mathrm{p}<0.01)$ higher than in controls $(1.35 \pm 0.27 \mathrm{pg} / \mathrm{ml})$. 


\section{Discussion}

We have established a sensitive RIA for determination of ET-3 in human plasma with a lower detection limit of $0.5 \mathrm{pg} / \mathrm{ml}$. The validity of this assay was demonstrated by the parallelity of plasma dilution curves to the standard curve. Intra- and interassay experiments showed the reliability and reverse-phase HPLC the specificity of the assay. Recoveries were considerably improved by a modification of the common extraction procedure, possibly as a result of precipitation of plasma proteins. Recovery rates were not significantly different between plasma of patients and controls.

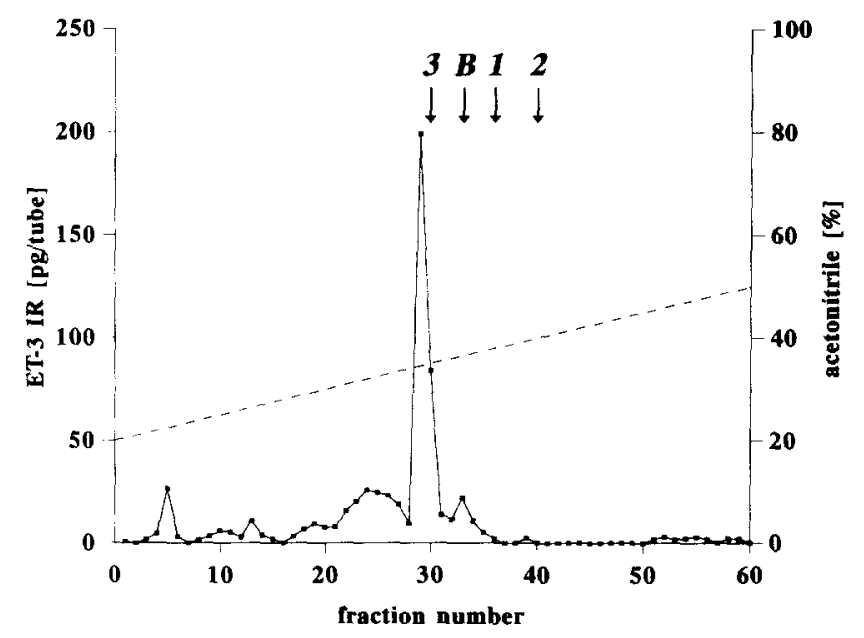

FIG. 3

Reverse-phase HPLC analysis of immunoreactive ET-3 in plasma from patients with cirrhosis of the liver. Arrows indicate the elution positions of ET-1 (1), ET-2 (2), ET-3 (3) and big ET-1 (B).

Mean plasma concentrations of ET-3 in healthy adults were found to be $1.35 \mathrm{pg} / \mathrm{ml}$, higher than the values detected by a sandwich-enzyme immunoassay (11). In cirrhotic patients ET-3 was raised threefold to a mean concentration of $4.16 \mathrm{pg} / \mathrm{ml}$.

Several mechanisms might account for increased ET-3 in cirrhosis. Elevated ET-3 plasma levels have been reported after sympathetic activation in healthy volunteers subsequent to strenuous exercise (12). Patients with cirrhosis of the liver exhibit an activation of the renin-angiotensin-aldosterone system (13) and of the sympathetic nervous system (9). An increase of plasma ET-3 could therefore be interpreted as a result of stimulated synthesis and release following sympathetic activation. On the other hand, ET-3 elevations could contribute to the vasodilation in cirrhosis and thus stimulate an activation of the sympathetic nervous system.

Plasma concentrations of peptides are determined not only by synthesis and release, but also by clearance and degradation (14). Therefore, another mechanism leading to increased ET-3 plasma levels could be a decreased renal clearance of ET-3, as described in patients undergoing chronic hemodialysis (15). The patients included in the present study, however, exhibited normal renal function.

Finally a decreased hepatic extraction of gut-derived ET-3 or a hepatic release in cirrhosis of the liver may be responsible for the elevated ET-3 plasma levels. The role of the liver in clearance of endothelins, however, has not been established so far and remains to be elucidated. Nevertheless, the finding of increased ET-3 plasma concentrations could suggest a role of this biologically active peptide in the hemodynamic changes of patients with cirrhosis of the liver. 


\section{Acknowledgments}

M. Bauch and F. Ringel are thanked for technical assistance. This study was supported by a grant from the Deutsche Forschungsgemeinschaft (Ge 576/2-2).

\section{References}

1. M. YANAGISAWA, H. KURIHARA, S. KIMURA, Y. TOMOBE, M. KOBAYASHI, Y, MITSUI, Y. YAZAKI, K. GOTO and T. MASAKI, Nature 332 411-415 (1988).

2. M.D. RANDALL, Pharmac. Ther. 50 73-93 (1991).

3. W.G. NAYLER, Trends Pharmacol. Sci. 11 96-99 (1990).

4. A. INOUE, M. YANAGISAWA, S. KIMURA, Y. KASUYA, T. MIYAUCHI, K. GOTO and T. MASAKI, Proc. Natl. Acad. Sci. 86 2863-2867 (1989).

5. W.K. SAMSON, K.D. SKALA, B.D. ALEXANDER and F.-L.S. HUANG, Biochem. Biophys. Res. Commun. 169 737-743 (1990).

6. T. MASAKI, S. KIMURA, M. YANAGISAWA and K. GOTO, Circulation 84 1457-1468 (1991).

7. A.C. LE MONNIER DE GOUVILLE, H. LIPPTON, G. COHEN, I. CAVERO and A. HYMAN, J. Pharmacol. Exp. Ther. 254 1024-1028 (1990).

8. N. FUKUDA, M. SOMA, Y. IZUMI, M. MINATO, Y. WATANABE, M. WATANABE and M. HATANO, Jpn. Circ. J. 55 617-622 (1991).

9. A.L. GERBES, Hepato-Gastroenterol. 38, 360-364 (1991).

10. H. MATSUMOTO, N. SUZUKI, H. ONDA and M. FUJINO, Biochem. Biophys. Res. Commun. 164 74-80 (1989).

11. N. SUZUKI, H. MATSUMOTO, T. MIYAUCHI, K. GOTO, T. MASAKI, M. TSUDA and M. FUJINO, Biochem. Biophys. Res. Commun. 169 809-815 (1990).

12. T. MIYAUCHI, Y. SUGISHITA, I. YAMAGUCHI, R. AJSAKA, O. MASATAKA, M. MATSUDA, I. KONO, M. YANAGISAWA, K. GOTO, N. SUZUKI, H. MATSUMOTO and T. MASAKI, J. Cardiovasc. Pharmacol. 17 (Suppl.7) S394-S397 (1991).

13. A.L. GERBES, H. WERNZE, R.M. ARENDT, A. RIEDEL, T. SAUERBRUCH and G. PAUMGARTNER, Hepatology 9 417-422 (1989).

14. A.L. GERBES and A.M. VOLLMAR, Life Sci. 47 1173-1180 (1990).

15. T. MIYAUCHI, N. SUZUKI, I. KURIHARA, I. YAMAGUCHI, Y. SUGISHITA, H. MATSUMOTO, K. GOTO and T. MASAKI, Biochem. Biophys. Res. Commun. 178 276281 (1991). 